\title{
Triterpenes from Hoya paziae Kloppenb.
}

\author{
Melissa Borlagdan ${ }^{1,2}$, Fernando B. Aurigue ${ }^{3}$, Ian A. Van Altena ${ }^{4}$, Consolacion Y. Ragasa ${ }^{1,5^{*}}$ \\ 'Department of Chemistry, De La Salle University, 2401 Taft Avenue, Manila 1004, PHILIPPINES. \\ 2Department of Science and Technology-Food and Nutrition Research Institute, Bicutan,Taguig, Metro Manila, PHILIPPINES. \\ 'Department of Science and Technology- Philippine Nuclear Research Institute, Commonwealth Avenue, Diliman, Quezon City 1101, PHILIPPINES. \\ ${ }^{4}$ School of Environmental and Life Sciences, Faculty of Science and Information Technology, The University of Newcastle-Australia, Callaghan, NSW, 2308, AUSTRALIA. \\ ${ }^{5}$ De La Salle University Science \& Technology Complex, Leandro V. Locsin Campus, Biñan City, Laguna 4024, PHILIPPINES.
}

\begin{abstract}
Chemical investigation of the dichloromethane extracts of the stems of Hoya paziae Kloppenb. led to the isolation of taraxerol (1), taraxeryl acetate (2), and a mixture $\alpha$-amyrin acetate (3), and $\beta$-amyrin acetate (4) in about 2.5:1 ratio. The structures of $\mathbf{1 - 4}$ were identified by comparison of their NMR data with those reported in the literature.

Keywords: Hoya paziae, Apocynaceae, taraxerol, taraxeryl acetate, $\alpha$-amyrin acetate, $\beta$-amyrin acetate
\end{abstract}

Corresponding author: ConsolacionY. Ragasa, Department of Chemistry, De La Salle University, 2401 Taft Avenue, Manila 1004, PHILIPPINES

Tel./Fax: +6325360230

Email: consolacion.ragasa@dlsu.edu.ph

DOI : $10.5530 /$ pj.2016.5.13

\section{INTRODUCTION}

Hoya is one of the genera of the family Apocynaceae that has been used as traditional medicine but it has become more useful as a source for ornamental plants due to its waxy foliage and attractive flowers. There are at least 109 species of Hoya found in the Philippines, 88 of these are endemic to the country. ${ }^{1}$ Unlike most other native hoyas, Hoya paziae is not a vine but an epiphytic shrub with scandent stems that tend to be pendent due to their own weights, especially when there are plenty of branches and foliage. The leaves are decussate instead of being opposite, while the flowers have white corolla with a purplish red and white corona. It was originally found in Antique, Oriental Mindoro, and Quezon provinces and is now commercialized locally and abroad as a hanging ornamental plant with blooms that last up to six days and emit a pleasantly sweet scent during the first day after opening. ${ }^{1}$ No report of the chemical constituents or ethnobotanical uses of the plant have been found.

This study is part of our research on the chemical constituents of Philippine endemic and indigenous hoyas. We earlier reported the isolation of lupenone and lupeol from the roots; lupeol, squalene and $\beta$-sitosterol from the leaves, and betulin from the stems of $H$. mindorensis Schlechter. ${ }^{2}$ In another study, we reported the isolation of lupeol, a-amyrin, $\beta$-amyrin, lupeol acetate, $\alpha$-amyrin acetate, and $\beta$-amyrin acetate from the stems; and $\alpha$-amyrin, bauerenol, squalene, lutein, $\beta$-sitosterol, and stigmasterol from the leaves of $H$. multiflora Blume. ${ }^{3}$ Recently, the isolation of $\beta$-amyrin cinnamate and taraxerol from the stems and taraxerol, triglycerides, chlorophyll a, and a mixture of $\beta$-sitosterol and stigmasterol from the leaves of $H$. wayetii Kloppenb. has been reported. ${ }^{4}$ Furthermore, the isolation of taraxerol, taraxerone, a mixture of $\beta$-sitosterol and stigmasterol, and a mixture of $\alpha$-amyrin cinnamate and $\beta$-amyrin cinnamate from the stems; taraxerol, taraxerone, and $\beta$-sitosterol from the roots; a mixture of $\alpha$-amyrin cinnamate and $\beta$-amyrin cinnamate from the flowers and squalene, $\beta$-sitosterol, and saturated hydrocarbons from the leaves of $H$. buotii has been reported. ${ }^{5}$ Most recently, we reported the isolation of $\beta$-amyrin cinnamate, squalene, $\beta$-sitosterol, a mixture of $\beta$-amyrin, $\alpha$-amyrin and lupeol and saturated hydrocarbons from the leaves and squalene, taraxerol, lupeol cinnamate, and a mixture of $\beta$-sitosterol and stigmasterol from the stems of $H$. diversifolia. ${ }^{6}$
We report herein the isolation of taraxerol (1), taraxeryl acetate (2), and a mixture $\alpha$-amyrin acetate (3) and $\beta$-amyrin acetate (4) in about 2.5:1 ratio from the stems of $H$. paziae. The chemical structures of compounds 1-4 are presented in Figure 1.

\section{MATERIALS AND METHODS}

\section{General Experimental Procedure}

NMR spectra were recorded on a Bruker Avance 400 spectrometer (400 MHz ${ }^{1} \mathrm{H}, 100 \mathrm{MHz}{ }^{13} \mathrm{C}$ ). Column chromatography was performed with silica gel 60 (70-230 mesh, Merck). Thin layer chromatography was performed with plastic backed plates coated with silica gel $\mathrm{F}_{254}$ and the plates were visualized by spraying with vanillin $/ \mathrm{H}_{2} \mathrm{SO}_{4}$ solution followed by warming.

\section{Sample Collection}

Healthy cuttings of $H$. paziae were collected from propagated plants at the Philippine Nuclear Research Institute Hoya Germplasm Collection under MTA No. 2015-004 dated March 20, 2015. Accession PNRI-H.30 was obtained from the Institute of Plant Breeding, University of the Philippines-Los Baños (UPLB) in 2008 when it was authenticated by Simeona V. Siar of the UPLB, Laguna, Philippines. The plant orginated from Quezon province.

\section{General Isolation Procedure}

A glass column 18 inches in height and 1 inch internal diameter was used for the fractionation of the crude extracts. Twenty $(20) \mathrm{mL}$ fractions

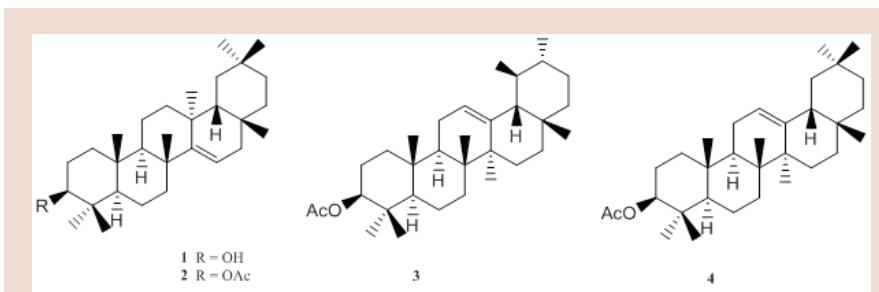

Figure 1: Chemical structures of taraxerol (1), taraxeryl acetate (2), a-amyrin acetate (3), and $\beta$-amyrin acetate (4) from Hoya paziae. 
were collected. A glass column 12 inches in height and 0.5 inch internal diameter was used for the rechromatography of fractions from the crude extracts. Two (2) mL fractions were collected. Fractions with spots of the same $R_{f}$ value were combined and rechromatographed in appropriate solvent systems until TLC pure isolates were obtained. Rechromatography and final purifications were conducted using Pasteur pipettes as columns. One (1) mL fractions were collected.

\section{Isolation of Chemical Constituents}

The air-dried stems (169.9 g) of $H$. paziae were ground in an Osterizer blender, soaked in $\mathrm{CH}_{2} \mathrm{Cl}_{2}$ for three days and then filtered. The filtrate was concentrated under vacuum to afford a crude extract $(7 \mathrm{~g})$ which was chromatographed by gradient elution with $\mathrm{CH}_{2} \mathrm{Cl}_{2}$, followed by increasing amounts of acetone by $10 \%$ increments by volume. The $\mathrm{CH}_{2} \mathrm{Cl}_{2}$ fraction was rechromatographed $(2 \times)$ using $2.5 \%$ EtOAc in petroleum ether to yield a mixture of $\mathbf{3}$ and $\mathbf{4}(4 \mathrm{mg})$ after washing with petroleum ether. The $20 \%$ acetone in $\mathrm{CH}_{2} \mathrm{Cl}_{2}$ fraction was rechromatographed $(3 \times)$ using $2.5 \%$ EtOAc in petroleum ether to afford $2(2 \mathrm{mg})$. The $30 \%$ acetone in $\mathrm{CH}_{2} \mathrm{Cl}_{2}$ fraction was rechromatographed $(3 \times)$ using $5 \%$ EtOAc in petroleum ether to yield 1 ( $3 \mathrm{mg})$ after washing with petroleum ether.

\section{RESULTS AND DISCUSSION}

Silica gel chromatography of the dichloromethane extract of $H$. paziae yielded compounds 1-4. Their NMR spectra are in accord with data reported in the literature for taraxerol ${ }^{5}$ (1), taraxeryl $\operatorname{acetate}^{7}(2)$, $\alpha$-amyrin $\operatorname{acetate}^{8}(3)$, and for $\beta$-amyrin acetate ${ }^{8}(4)$. The 2.5:1 ratio of the mixture of $\alpha$-amyrin acetate (3) and $\beta$-amyrin acetate (4) was deduced from the intensities and integrations of the ${ }^{1} \mathrm{H}$ NMR resonances for the olefinic protons of 3 at $\delta 5.11(\mathrm{t}, J=3.6 \mathrm{~Hz})$ and $\delta 5.16(\mathrm{t}, J=3.6 \mathrm{~Hz})$ of 4 .
These results indicate that $H$. paziae shares similar chemical characteristics with other members of the genus Hoya: H. wayetii, ${ }^{4}{ }^{H}$. buotii ${ }^{5}$ and H. diversifolia ${ }^{6}$ which yielded taraxerol (1); and H.multiflora ${ }^{3}$ which afforded $\alpha$-amyrin acetate (3) and $\beta$-amyrin acetate (4). This is the first report on the isolation of taraxeryl acetate from Philippine native hoyas.

\section{ACKNOWLEDGEMENTS}

A research grant from the De La Salle University Science Foundation through the University Research Coordination Office is gratefully acknowledged.

\section{CONFLICT OF INTEREST}

The authors declare no conflict of interest.

\section{REFERENCES}

1. Aurigue FB. 2013. A Collection of Philippine Hoyas and Their Culture, Philippine Council for Agriculture, Aquatic and Natural Resources Research and Development (PCAARRD). Department of Science and Technology (DOST). 195 pages.

2. Ebajo Jr VD, Shen CC, Ragasa CY. Triterpenes and sterol from Hoya mindorensis. Der Pharma Chemica. 2014; 6(4):321-5.

3. Ebajo Jr VD, Shen CC, Ragasa CY. Terpenoids and sterols from Hoya multiflora Blume. J Appl Pharm Sci. 2015;5(3):33-9.

4. Ebajo Jr VD, Aurigue FB, Brkljaca R, Urban S, Ragasa CY. Chemical constituents of Hoya wayetii Kloppenb. Int J Pharmacog Phytochem Res. 2015; 7(5):1041-5.

5. Ebajo Jr VD, Brkljaca R, Urban S, Ragasa CY. Chemical constituents of Hoya buotii Kloppenb. J Appl Pharm Sci. 2015; 5(11):69-72.

6. Panajon NM, Aurigue FB, Shen CC, Ragasa CY. Triterpenes and sterols from Hoya diversifolia Blume. J Appl Pharm Sci. 2016;6(6):79-82.

7. Thuy TT, Sung TV, Frank K, Wessjohann L. Triterpenes from the roots of Codonopsis pilosula. J Chem. 2008;46(4):515- 20

8. Feleke S, Brehane A. Triterpene compounds from the latex of Ficus sur I. Bull Chem Soc Ethiop. 2005;19(2):307-10.

\section{PICTORIAL ABSTRACT}

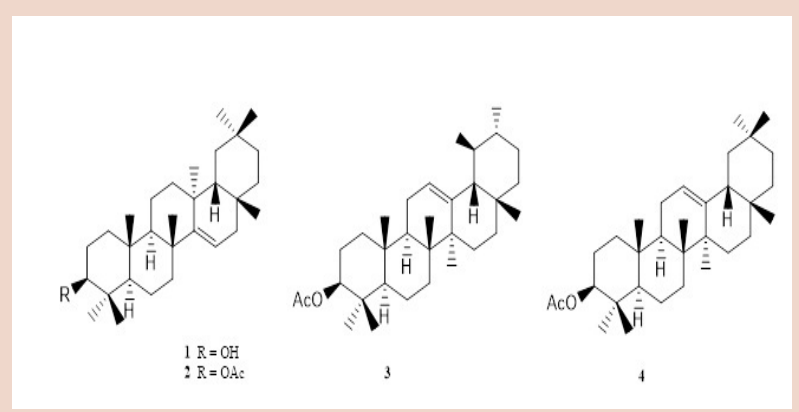

\section{SUMMARY}

- This is the first study on the chemical constituents of Hoya paziae, an ornamental plant native to the Philippines.

- The dichloromethane extracts of the stems of $H$. paziae yielded the triterpenes taraxerol, taraxeryl acetate, $\alpha$-amyrin acetate, and $\beta$-amyrin acetate.

- H. paziae shares similar chemical characteristics with other members of the genus Hoya: $H$. wayetii, $H$. buotii and $H$. diversifolia which yielded taraxerol; and $H$. multiflora which afforded $\alpha$-amyrin acetate and $\beta$-amyrin acetate.

- This is the first report on the isolation of taraxeryl acetate from Philippine native hoyas.

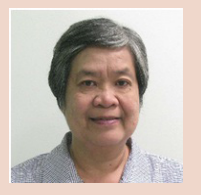

\section{ABOUT AUTHORS}

Consolacion Y. Ragasa: Obtained her Ph. D. in Chemistry from the University of the Philippines - Diliman. Dr. Ragasa is a Full Professor of the Chemistry Department and a University Fellow of De La Salle University - Manila. Her research focuses on the isolation and structure elucidation of the chemical constituents of Philippine plants. She has published extensively in natural products, phytochemistry and pharmacognosy journals. Dr. Ragasa was awarded the Pillar of Lasallian Excellence Award in Research (2013), National Research Council of the Philippines Achievement Award in Chemical Research (2003), Philippine Federation of Chemistry Societies Achievement Award in Chemical Research (2002), and St. Miguel Febres Cordero Research Award (SY 20002001). She is a member of the editorial board of several international and national journals. 


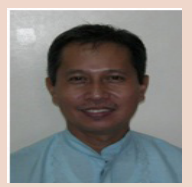

Fernando B. Aurigue: Obtained his Master of Science in Plant Breeding (Horticulture) from the University of the Philippines - Los Baños, College, Laguna, Philippines where he also obtained his Bachelor of Science in Agriculture, Major in Horticulture, Minor in Plant Tissue Culture and Embryology. He is a Professional Regulations Commission-Registered Agriculturist, an accredited researcher of the National Research Council of the Philippines, a member of the Philippine Council for Agriculture, Aquatic and Natural Resources Research and Development Pool of Experts in Medicinal and Ornamental Crops, and a Senior Science Research Specialist at the Philippine Nuclear Research Institute-Department of Science and Technology. His research works on the genus * Hoya* have been recognized by the Flora Malesiana Foundation and his contributions to the advancement of Horticulture in the Philippines made him an Honorary Member of the Philippine Horticultural Society, Inc.

Ian van Altena: Is a lecturer in chemistry in the School of Environmental and Life Sciences, The University of Newcastle-Australia. He lectures courses in organic and environmental chemistry and conducts research programs in the area of natural products chemistry. He has a particularly interest in medicinal plants, algal chemotaxonomy and marine chemical ecology. Day-to-day research is driven by the isolation of compounds from plants and marine invertebrate and their structure elucidation mainly by nuclear magnetic resonance spectroscopy and mass spectrometry.

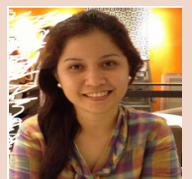

Melissa Sausa Borlagdan: Is a graduate student of De La Salle University taking Master of Science in Chemistry. She graduated Bachelor of Science in Biochemistry at the University of the Philippines -Manila. She is currently employed as Science Research Specialist I at the Food and Nutrition Research Institute Department of Science and Technology (FNRI-DOST). She works on projects studying nutrient availability, dietary fiber composition, phytochemical and glycemic index of different food sources. 